\title{
GAMBARAN PENGETAHUAN TENTANG DAMPAK PERNIKAHAN DINI PADA REMAJA PUTERI KELAS XI DI SMK NEGERI 1 LIMBOTO
}

\author{
${ }^{1}$ Sri Dewi Palindrawati Lihu, ${ }^{2}$ Fifi Ishak, ${ }^{3}$ Sisilia S. Kasa \\ 1,2,3)Program Studi DIV Bidan Pendidik Universitas Muhammadiyah Gorontalo, \\ Gorontalo 96181, Indonesia \\ e-mail: sridewilihu@gmail.com
}

\begin{abstract}
This research was administered in SMKN 1 Limboto. The objective of this research is to give overview of knowledge about early marriage impact on teenage girls in Class XI SMKN 1 Limboto. This research is descriptive and the sample involved in this research consists of 125 respondents. The sampling technique is purposive sampling. Based on the result, it is found that respondents with good level of knowledge are 18 respondents (14,4\%), respondents with average level of knowledge are 66 respondents (52,8\%), and respondents with low level of knowledge are 41 respondents (32,8\%). So it can be concluded that An Overview of Knowledge Of Early Marriage Impact on Teenage Girls Class XI in SMKN 1 Limboto most in the category enough that is 66 respondents.
\end{abstract}

Key words: knowledge, early marriage, teenage girls.

\section{Abstrak}

Penelitian ini dilakukan di SMK Negeri 1 Limboto. Tujuan penelitian ini untuk mengetahui gambaran pengetahuan tentang dampak pernikahan dini pada remaja puteri kelas XI di SMK Negeri 1 Limboto. Jenis penelitian yang digunakan adalah penelitian deskriptif dengan sampel yang berjumlah 125 responden. Teknik pengambilan sampel yang di gunakan adalah tekhnik purposive sampling. Dari hasil penelitian yang di lakukan di dapatkan bahwa responden dengan tingkat pengetahuan baik berjumlah 18 responden (14.4\%), responden dengan tingkat pengetahuan cukup berjumlah 66 responden (52.8\%), dan responden dengan tingkat pengetahuan kurang berjumlah 41 (32.8\%) responden. Jadi dapat disimpulkan bahwa gambaran pengetahuan tentang dampak pernikahan dini pada remaja puteri di SMK Negeri 1 Limboto yang terbanyak berada pada kategori cukup yaitu 66 responden.

Kata Kunci : Pengetahuan, pernikahan dini, remaja puteri

\section{PENDAHULUAN}

Usia remaja merupakan masa transisi dari anak-anak ke dewasa yang disertai dengan perubahan fisik dan psikis. Ditinjau dari bidang kegiatan WHO yakni kesehatan, masalah terutama yang dirasakan mendesak mengenai kesehatan 
remaja ialah kehamilan yang terlalu awal karena usia pernikahan yang terlalu muda pula (Sarwono, 2011). Usia kehamilan yang terlalu awal memiliki beberapa dampak seperti meningkatnya angka pertumbuhan penduduk dan risiko komplikasi kehamilan pada ibu usia muda.

Pernikahan merupakan suatu hal yang penting dalam realita kehidupan umat manusia, dengan adanya pernikahan rumah tangga dapat ditegakkan dan dibina sesuai dengan norma agama dan tata kehidupan masyarakat.

Perkawinan usia muda tidak hanya memiliki dampak pada pertambahan penduduk yang semakin tinggi tetapi perkawinan di usia muda juga dapat memiliki dampak pada kesehatan wanita yang melakukan perkawinan pada saat usia muda (Zainuri, 1990). Wanita yang melakukan perkawinan di usia muda atau melakukan hubungan seks secara dini memiliki risiko terkena kanker leher rahim atau kanker serviks (Bustan, 2007). Berdasarkan hasil penelitian, wanita yang paling baik untuk melahirkan adalah usia 2030 tahun sedangkan melahirkan pada usia muda atau remaja (usia di bawah 20 tahun) dapat menimbulkan akibat buruk tidak saja bagi kesehatan ibu tapi juga bagi bayi yang dilahirkan

Sebuah penelitian di Amerika Latin dan Karibia menunjukkan bahwa $29 \%$ wanita muda menikah saat mereka berusia 18 tahun. Prevalensi tinggi kasus pernikahan usia dini tercatat di Nigeria (79\%), Kongo (74\%), Afganistan (54\%), dan Banghladesh (51\%). Praktek pernikahan usia dini paling banyak terjadi di Afrika dan Asia Tenggara.
Data di Asia Tenggara didapatkan bahwa sekitar 10 juta anak usia dibawah 18 tahun telah menikah. Sedangkan di Afrika diperkirakan 42\% dari populasi anak, menikah sebelum mereka berusia 18 tahun. Hasil penelitian UNICEF di Indonesia, menemukan angka kejadian pernikahan anak berusia 15 tahun berkisar $11 \%$, sedangkan yang menikah disaat usia tepat 18 tahun sekitar 35\%. Secara umum, pernikahan anak lebih sering terjadi pada anak perempuan dibandingkan anak laki-laki, sekitar $5 \%$ anak laki-laki menikah sebelum mereka berusia 19 tahun.

Indonesia termasuk negara dengan persentase pernikahan dini cukup tinggi di dunia, dengan menempati urutan ke-37. Sedangkan di ASEAN, Indonesia menduduki urutan kedua setelah Kamboja (Hardinoto, 2012). Data Badan Koordinasi Keluarga Berencana (BKKBN) Indonesia 2012 menunjukkan prevalensi umur perkawinan usia dibawah 20 tahun sebanyak 1.765 .071 atau $3.88 \%$.

Di Provinsi Gorontalo pada tahun 2012 wanita yang menikah dibawah usia 20 tahun sebanyak 7.372 atau $3,60 \%$, sedangkan pada tahun 2013 berdasarkan data Survei Demografi Kesehatan Indonesia (SDKI) angka kejadian pernikahan dini mencapai $15,3 \%$. Berdasarkan data yang dihimpun dari Dinas Kependudukan dan Pencatatan Sipil Kabupaten Gorontalo, pada tahun 2014 jumlah wanita yang menikah pada usia 12-19 tahun berjumlah 1898. Sedangkan pada tahun 2015 jumlah wanita yang menikah pada usia 12-19 tahun berjumlah 994. 
Berdasarkan data tersebut kecamatan Limboto berada di urutan pertama dalam kasus pernikahan dini yaitu sebanyak 92 orang. Berdasarkan data tersebut peneliti tertarik untuk meneliti di wilayah Kecamatan Limboto, karena penelitian ini berhubungan dengan remaja puteri maka peneliti melakukan penelitian di sekolah SMK Negeri 1 Limboto dengan jumlah siswi kelas XI berjumlah 183 orang dari 9 program keahlian yang terbagi dalam 16 kelas yang ada disekolah tersebut.

Berdasarkan survei pendahuluan yang dilakukan oleh peneliti terhadap siswi, sebagian besar responden belum mengetahui dampak dari pernikahan dini. Berdasarkan keterangan yang diperoleh dari guru bimbingan konseling setiap tahun ada siswi yang di keluarkan atau pindah sekolah dengan berbagai macam alasan. Salah satu alasannya adalah siswi yang sudah terlanjur hamil. Hal ini di buktikan bahwa pada tahun 2015 ada 3 orang siswi yang di keluarkan dan pada tahun 2016 masih terdapat 3 siswi yang dikeluarkan akibat hamil diluar nikah.

Pernikahan usia dini juga akan berimplikasi pada keterbelakangan pengetahuan akibat terhambatnya proses pendidikan disebabkan pernikahan tersebut. Aspek sosial budaya masyarakat memberi pengaruh terhadap pelaksanaan pernikahan dan tidak terlepas pula pada pernikahan usia dini.

Ini dibuktikan oleh Karlinda Nuriya Afifah dan Dwi Susilawati dalam penelitiannya pada tahun 2016 dengan judul penelitian "Gambaran Pengetahuan Remaja Puteri Tentang
Dampak Pernikahan Dini Di Desa Lempong Kecamatan Jenawi Kabupaten Karanganyar." Berdasarkan hasil penelitian ini menunjukkan bahwa dari 168 responden, sebanyak 75 orang $(44,6 \%)$ berpengetahuan kurang, sebanyak 68 orang (40,5\%) berpengetahuan cukup, dan sebanyak 25 orang $(14,9 \%)$ berpengetahuan baik.

Kurangnya pengetahuan tersebut juga bisa disebabkan oleh kurangnya pengalaman dan keterpaparan remaja terhadap suatu informasi yang dapat mengubah pengetahuan, sikap, dan perilaku yang dimiliki. Responden penelitian menyadari kurangnya pengetahuan ini disebabkan institusi pendidikan maupun pelayanan kesehatan jarang melakukan penyuluhan tentang bahaya pernikahan dini kepada masyarakat khususnya kepada remaja puteri.

Berdasarkan latar belakang dari masalah di atas, maka rumusan masalah dalam penelitian ini adalah "Bagaimana gambaran pengetahuan tentang dampak pernikahan dini pada remaja puteri kelas XI di SMK Negeri 1 Limboto?". Adapun tujuan umum dari penelitian ini adalah Untuk mengetahui gambaran pengetahuan tentang dampak pernikahan dini pada remaja puteri kelas XI di SMK Negeri 1 Limboto sedangkan tujuan khususnya yaitu untuk mengetahui sejauh mana remaja puteri tahu tentang dampak pernikahan dini dan untuk mengetahui sejauh mana remaja puteri memahami tentang dampak pernikahan dini. 


\section{METODE PENELITIAN}

Penelitian ini dilaksanakan pada tanggal 4 februari sampai dengan 22 februari 2017 di SMK Negeri 1 Limboto.

Metode penelitian yang digunakan adalah metode penelitian kuantitatif, dan semi kualitatif. Penelitian kuantitatif adalah penelitian yang mengambil sampel dari suatu populasi dan menggunakan kuesioner sebagai alat pengumpulan data yang pokok.

Dalam penelitian ini variabelnya adalah pengetahuan tentang dampak pernikahan dini.

Populasi yang akan diambil dalam penelitian ini adalah seluruh siswi remaja puteri kelas XI di SMK Negeri 1 Limboto yang berjumlah 183 orang.

Teknik pengambilan sampel ini menggunakan teknik Purposive Sampling. Purposive sampling adalah tekhnik penentuan sampel dengan pertimbangan tertentu. (Sugiyono, 2011). Berdasarkan perhitungan rumus:

$$
\begin{aligned}
\mathrm{n} & =\frac{\mathrm{N}}{1+\mathrm{N}(\mathrm{d})^{2}} \\
& =\frac{183}{1+183(0,0025)} \\
& =125
\end{aligned}
$$

Jadi, jumlah sampel dalam penelitian ini yaitu sebanyak 125 orang.

\section{INTRUMEN PENELITIAN}

Instrument yang digunakan dalam pengumpulan data adalah menggunakan kuesioner yang di persiapkan sebelumnya. Berisi tentang pertanyaan pengetahuan tentang dampak pernikahan dini dengan memberikan pertanyaan, dimana responden tinggal memilih salah satu jawaban pada lembar kuesioner yang disediakan.

\section{HASIL DAN PEMBAHASAN}

Karakteristik Responden

Penelitian ini ditujukan kepada para siswi karena penelitian ini mengambil tema pernikahan dini pada remaja puteri kelas XI di SMK Negeri 1 Limboto. Pada siswi kelas XI, umur yang tertua adalah $>17$ tahun dan yang termuda adalah 15 tahun. Pada pengambilan data awal didapatkan jumlah siswi kelas XI berjumlah 183 . Oleh karena itu, peneliti mengambil siswi kelas XI yang kemudian dilakukan pengambilan sampel dengan menggunakan Purposive Sampling. Sehingga sampel yang didapatkan yaitu sebanyak 125 responden yang ada di SMK Negeri 1 Limboto.

Tabel 1. Umur siswi kelas XI SMK Negeri 1 Limboto

\begin{tabular}{ccc}
$\begin{array}{c}\text { Umur } \\
\text { (Tahun) }\end{array}$ & Frekuensi & $\begin{array}{c}\text { Persentase } \\
(\%)\end{array}$ \\
\hline 15 & 7 & 5.6 \\
16 & 64 & 51.2 \\
$>17$ & 54 & 43.2 \\
Jumlah & 125 & 100 \\
\hline
\end{tabular}

Sumber: Olahan data primer (2017)

Berdasarkan Tabel 1, diketahui bahwa sebagian besar responden berumur 16 tahun yakni sebanyak 64 responden (51.2\%), dan sebagian kecil berumur 15 tahun yaitu sebanyak 7 responden (5.6 \%).

Pengetahuan tentang dampak pernikahan dini pada remaja puteri 
Berdasarkan hasil penelitian yang disajikan pada Tabel 2 diketahui bahwa dari 125 responden diketahui responden dengan tingkat pengetahuan terbanyak yaitu pada kategori cukup sebanyak 65 responden (52.0\%), dan tingkat tahu yang paling sedikit ada pada kategori baik yaitu 23 responden (18.4\%).

Tabel 2. Distribusi yang tahu tentang dampak pernikahan dini pada remaja puteri di SMK Negeri 1 Limboto

\begin{tabular}{lcc}
\hline $\begin{array}{c}\text { Tingkat } \\
\text { pengetahuan }\end{array}$ & Jumlah & $\begin{array}{c}\text { Persentase } \\
(\%)\end{array}$ \\
\hline Baik & 23 & 18.4 \\
Cukup & 65 & 52.0 \\
Kurang & 37 & 29.6 \\
Total & 125 & 100 \\
\hline \multicolumn{2}{c}{ Sumber: Olahan data primer (2017) }
\end{tabular}

\section{Pemahaman tentang dampak pernikahan dini pada remaja puteri}

Tabel 3. Distribusi pemahaman tentang dampak pernikahan dini pada remaja puteri di SMK Negeri 1 Limboto

\begin{tabular}{ccc}
\hline $\begin{array}{c}\text { Tingkat } \\
\text { Pemahaman }\end{array}$ & Jumlah & $\begin{array}{c}\text { Persentase } \\
(\%)\end{array}$ \\
\hline Baik & 15 & 12.0 \\
Cukup & 38 & 30.4 \\
Kurang & 72 & 57.6 \\
Total & 125 & 100 \\
\hline
\end{tabular}

Sumber: Olahan data primer (2017)

Hasil penelitian juga menunjukkan bahwa dari 125 responden diketahui responden dengan tingkat pemahaman terbanyak yaitu pada kategori kurang sebanyak 72 responden (57.6 \%), dan tingkat pengetahuan yang paling sedikit ada pada kategori baik yaitu 15 responden $(12.0 \%)$ sebagaimana tampak pada Tabel 3.

Berdasarkan dari hasil 2 parameter diatas, di dapatkan hasil secara keseluruhan pengetahuan tentang dampak pernikahan dini pada remaja puteri di SMK Negeri 1 Limboto, yaitu:

Tabel 4. Distribusi gambaran pengetahuan tentang dampak pernikahan dini pada remaja puteri di SMK Negeri 1 Limboto

\begin{tabular}{|c|c|c|}
\hline $\begin{array}{c}\text { Tingkat } \\
\text { Pengetahuan }\end{array}$ & Jumlah & $\begin{array}{c}\text { Persentase } \\
(\%)\end{array}$ \\
\hline Baik & 18 & 14.4 \\
\hline Cukup & 66 & 52.8 \\
\hline Kurang & 41 & 32.8 \\
\hline Total & 125 & 100 \\
\hline
\end{tabular}
responden dapat diketahui responden dengan tingkat pengetahuan baik sebanyak 18 responden (14.4\%), sedangkan responden dengan tingkat pengetahuan cukup sebanyak 66 responden (52.8\%), dan responden dengan tingkat pengetahuan kurang sebanyak 41 responden (32.8\%).

Dapat disimpulkan bahwa gambaran pengetahuan tentang dampak pernikahan dini pada remaja puteri di SMK Negeri 1 Limboto yang terbanyak berada dalam kategori cukup yaitu 66 responden (52.8\%), selanjutnya dapat dilihat dalam bentuk grafik di bawah ini: 


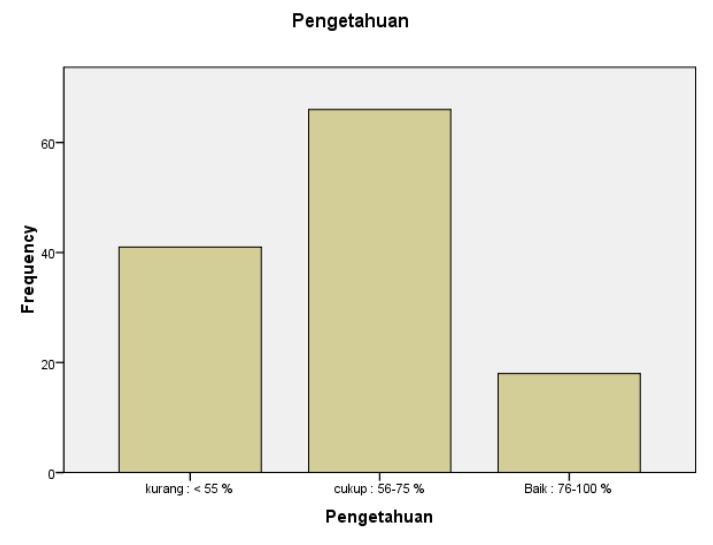

Gambar 1. Distribusi gambaran pengetahuan tentang dampak pernikahan dini pada remaja puteri kelas $\mathrm{XI}$ di SMK Negeri 1 Limboto

Tabel 5. Distribusi tahu dan pemahaman tentang dampak pernikahan dini pada remaja puteri di SMK Negeri 1 Limboto
$8.8 \%$, sementara responden dengan tahu baik dan pemahaman baik tentang dampak pernikahan dini yaitu sebanyak $2.4 \%$.

Responden dengan tahu cukup dan pemahaman kurang tentang dampak pernikahan dini sebanyak $30.4 \%$, sedangkan yang tahu cukup dan pemahaman kurang tentang dampak pernikahan dini yaitu sebanyak $15.2 \%$, serta responden dengan tahu cukup dengan pemahaman baik tentang dampak pernikahan dini yaitu sebanyak $6.4 \%$.

Responden dengan tahu kurang dan pemahaman kurang tentang dampak pernikahan dini pada remaja puteri yaitu sebanyak $20 \%$, sedangkan responden dengan tahu kurang serta pemahaman cukup tentang dampak pernikahan dini sebanyak $6.4 \%$, serta tahu kurang dengan pemahaman baik tentang dampak pernikahan dini yaitu sebanyak $3.2 \%$.

Gambaran pengetahuan tentang dampak pernikahan dini pada remaja

Pemahaman Tentang puteri kelas XI di SMK Negeri 1 No Tahu Dampak Pernikahan Dini Limboto dari 125 responden terdapat No Tahu $\begin{array}{lllll}\text { Kurang } & \text { Cukup } & \text { Baik } 41 & \text { responden }(32.8 \%) \text { yang }\end{array}$ $\begin{array}{llllllll}\mathrm{N} & \% & \mathrm{~N} & \% & \mathrm{~N} & \text { \%berpengetahuan kurang, } & 66\end{array}$

$\begin{array}{llllllllll}1 & \text { Baik } & 9 & 7.2 & 11 & 8.8 & 3 & 2.4 e s p o n d e n & (52.8 & \%)\end{array}$

2 Cukup $38 \quad 30.4 \quad 19 \quad 15.2 \quad 8 \quad 6.4$ erpengetahuan cukup, dan terdapat

3 Kurang $25 \quad 20 \quad 8 \quad 6.4 \quad 4 \quad 3.2^{8} \quad$ responden $(14.4 \quad \%)$ yang

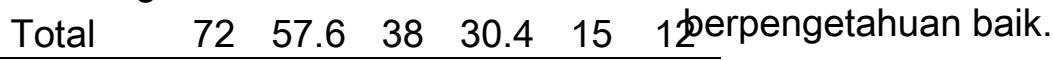

Sumber: Olahan data primer (2017)

Berdasarkan tabel 2, dari 125 responden diketahui responden dengan tingkat tahu terbanyak yaitu

Berdasarkan tabel 5 menunjukkan bahwa responden dengan tahu baik dan pemahaman kurang tentang dampak pernikahan dini yaitu sebanyak $7.2 \%$, sedangkan responden dengan tahu baik dan pemahaman cukup yaitu sebanyak pada kategori cukup sebanyak 65 responden (52.0\%), dan tingkat tahu yang paling sedikit ada pada kategori baik yaitu 23 responden (18.4\%). Tahu di artikan sebagai mengingat sesuatu yang dipelajari sebelumnya. Termasuk dalam pengetahuan tingkat 
ini adalah mengingat kembali (recal) sesuatu spesifik dari suatu bahan yang di terima atau dipelajari.

Berdasarkan tabel 3, dari 125 responden diketahui responden dengan tingkat pengetahuan terbanyak yaitu pada kategori kurang sebanyak 72 responden (57.6\%), dan tingkat pengetahuan yang paling sedikit ada pada kategori baik yaitu 15 responden (12.0 \%). Memahami (comprehension) adalah kemampuan untuk menjelaskan tentang obyek yang diketahui dan menginterpestasikan materi tersebut secara benar.

Berdasarkan tabel 4, dari 125 responden dapat diketahui responden dengan tingkat pengetahuan baik sebanyak 18 responden (14.4\%), sedangkan responden dengan tingkat pengetahuan cukup sebanyak 66 responden (52.8\%), dan responden dengan tingkat pengetahuan kurang sebanyak 41 responden (32.8\%).

Setelah peneliti membagikan kuesioner kepada responden yang terdiri dari 14 pertanyaan pengetahuan tentang penikahan dini pada remaja puteri, responden tinggal memilih jawaban yang telah di sediakan dalam kuesioner tersebut. Dari hasil kuesioner tersebut menunjukkan dari 125 responden yang memiliki pengetahuan baik yaitu 18 responden dari hasil wawancara yang menyebabkan responden bisa menjawab pertanyaan dengan benar, karena responden mencari tahu sendiri informasi tentang pernikahan dini melalui media sosial, dan melihat di televisi sehingga responden bisa memahami tentang pernikahan dini dengan baik, sedangkan responden yang memiliki pengetahuan cukup yaitu 66 responden, dari hasil wawancara yang dilakukan peneliti terhadap 66 responden yang berpengetahuan cukup diakibatkan karena kurangnya sosialisasi dari tenaga medis kesehatan dan responden yang memiliki pengetahuan kurang yaitu 41 responden, berdasarkan hasil wawancara yang dilakukan oleh peneliti kepada 41 responden yang belum bisa menjawab pertanyaan dengan benar penyebabnya karena responden sama sekali tidak tahu tentang pernikahan dini, responden tidak pernah mengikuti penyuluhan yang berhubungan dengan pernikahan dini dan tidak pernah mencari tahu informasi mengenai pernikahan dini.

Sedangkan hasil penelitian pada tabel 5 menunjukkan bahwa 125 responden terdapat 25 (20,0 \%) dengan pengetahuan kurang serta pemahaman juga kurang tentang pernikahan dini, hal ini disebabkan karena dari 25 resonden tersebut tidak mengetahui tentang pernikahan dini dan responden tidak pernah mendapatkan informasi mengenai pernikahan dini sehingga responden tidak memahami dampak yang akan ditimbulkan jika melakukan pernikahan dini. Sedangkan responden dengan pengetahuan cukup tetapi pemahaman kurang tentang pernikahan dini yaitu sebanyak 38 responden $(30,4 \%)$. Penyebab dari 38 responden dengan pengetahuan cukup tetapi pemahaman kurang tentang pernikahan dini karena kurangnya informasi mengenai pernikahan dini 
serta kurangnya sosialisasi yang di peroleh responden mengenai pernikahan dini.

Selain itu juga, responden dalam kategori umur yang telah peneliti lakukan yang terbanyak berada pada usia 16 tahun dimana pada usia tersebut remaja bisa menerima informasi dengan baik tetapi belum sepenuhnya paham atas informasi yang didapat. Hal ini sama dengan penelitian Menurut Bobak (2006) dalam Damayanti (2012), umur mempengaruhi pengetahuan dimana umur 16 tahun merupakan tahap remaja madya dimana belajar menerima informasi tetapi belum mampu menerapkan informasi tersebut secara maksimal dan sering kali mencoba-coba tanpa memperhitungkan konsekuensinya, sedangkan umur 17-18 tahun merupakan remaja akhir dimana mulai memahami dirinya dan lebih mudah menerima informasi sehingga mempengaruhi pengetahuan mereka terutama tentang pernikahan dini. Selain berpengaruh pada umur, pengetahuan seseorang berpengaruh juga pada:

1) Pengalaman

Pengalaman merupakan suatu cara untuk memperoleh kebenaran pengetahuan, baik dari pengalaman diri sendiri maupun orang lain. Hal tersebut dilakukan dengan cara pengulangan kembali pengalaman yang diperoleh dalam memecahkan permasalahan yang dihadapi. Bila berhasil maka orang akan menggunakan cara tersebut dan bila gagal tidak akan mengulangi cara itu.

2) Pendidikan

Makin tinggi tingkat pendidikan seseorang, maka makin mudah menerima informasi sehingga makin banyak pula pengetahuan yang dimiliki. Sebaliknya pendidikan yang kurang akan menghambat perkembangan sikap seseorang terhadap nilai-nilai baru yang diperkenalkan.

3) Kepercayaan

Kepercayaan adalah sikap untuk menerima suatu pernyataan atau pendirian tanpa menunjukkan sikap pro atau anti kepercayaan. Sering diperoleh dari orang tua, kakek atau nenek. Seseorang menerima kepercayaan itu berdasarkan keyakinan dan tanpa adanya pembuktian terlebih dahulu. Kepercayaan berkembang dalam masyarakat yang mempunyai tujuan dan kepentingan yang sama. Kepercayaan dapat tumbuh bila berulang kali mendapatkan informasi yang sama.

Penelitian ini juga didukung oleh penelitian terdahulu yang dilakukan oleh Handayani (2014) dalam Susilawati (2016) mengenai gambaran pengetahuan remaja puteri tentang dampak pernikahan dini bagi kesehatan di SMA An-Naas Pekanbaru diketahui bahwa mayoritas responden berpengetahuan cukup tentang dampak pernikahan dini bagi kesehatan yaitu sebanyak 36 responden (56,26\%). Pengetahuan remaja yang termasuk kategori pengetahuan cukup juga dapat membantu seseorang untuk menunda pernikahan. Apabila semakin banyak remaja puteri yang beranggapan untuk menunda pernikahannya maka akan berdampak pada penurunan angka pernikahan dini. Pengetahuan seseorang salah satunya dipengaruhi oleh faktor usia. Responden penelitian 
ini mayoritas berusia 15-17 tahun yaitu sebanyak 101 orang dari 168 responden $(60,1 \%)$. Remaja pada usia ini termasuk dalam kategori remaja madya atau remaja pertengahan. Tahapan tumbuh kembang yang sedang dialami remaja pertengahan seperti: mulai mempererat hubungan dengan teman maupun lawan jenis, timbul adanya keinginan untuk kencan, telah merasa perlu mengumpulkan pengalaman baru walaupun beresiko seperti seks bebas, serta merasa berada dalam kondisi kebingungan karena ia belum bisa melakukan keputusan (Desmita, 2009). Salah satu keputusan tersebut dapat dilihat ketika remaja puteri diminta mengisi kuesioner mengenai pengetahuan tentang pernikahan dini, mereka tampak kebingungan dalam mengambil keputusan. Hal inilah menjadi salah satu faktor yang menyebabkan sebagian besar responden termasuk dalam kategori berpengetahuan cukup dan kurang.

Usia remaja seringkali menimbulkan berbagai persoalan dari berbagai sisi, karena pada masa ini remaja selalu ingin mencoba-coba apa yang di ketahuinya. Salah satunya adalah seperti menikah pada usia dini karena keterlanjuran berhubungan seks yang menyebabkan suatu kehamilan. Padahal, dampak pernikahan dini sangatlah berbahaya bagi remaja itu sendiri baik secara psikis ataupun secara fisik.

Remaja juga belum siap secara psikis untuk menikah, karena pada usia remaja emosi masih labil, remaja masih kurang mampu untuk bersosialisasi dan adaptasi, dikarenakan ego remaja yang masih tinggi serta belum matangnya sisi kedewasaan untuk berkeluarga sehingga banyak ditemukannya kasus perceraian yang merupakan dampak dari mudanya usia untuk menikah. Hal inilah yang menyebabkan berbagai dampak negatif akibat adanya pernikahan dini.

Berbagai dampak pernikahan dini baik secara fisik ataupun secara psikis, masyarakat pada umumnya tidak menghendaki remaja mereka melakukan kegiatan seksual sebelum menikah. Oleh sebab itu, mereka sering menabuhkan berbicara masalah seks dengan para remaja. Sedangkan dari segi psikologisnya pembicaraan mengenai seks dalam keluarga itu tabu karena pembicaraan itu dianggap sebagai dorongan naluri seksual yang bertentangan dengan dorongan "moral" yang ada dalam "super ego" sehingga harus ditekan, tidak boleh dimunculkan pada orang lain dalam bentuk tingkah laku terbuka.

\section{KESIMPULAN DAN SARAN}

Kesimpulan

Berdasarkan penelitian yang telah dilakukan, dapat disimpulkan bahwa Gambaran pengetahuan tentang dampak pernikahan dini pada remaja puteri kelas XI sebagian besar dalam kategori cukup yaitu sebanyak 66 responden, sedangkan berdasarkan tahu sebagian besar dalam kategori cukup yaitu sebanyak 65 responden dan berdasarkan pemahaman sebagian besar berada dalam kategori kurang yaitu sebanyak 72 responden. 


\section{Saran}

Berdasarkan pembahasan dan kesimpulan diatas yang menjadi saran peneliti adalah:

1. Bagi responden

Diharapkan dengan adanya penelitian ini, para siswi lebih memperdalam lagi pengetahuan mereka serta memahami tentang dampak pernikahan dini dan diharapkan responden mencari informasi tentang dampak yang akan ditimbulkan dari kejadian tersebut.

2. Bagi Institusi

Mampu memberikan informasi terhadap khalayak umum. Hasil penelitian ini diharapkan mampu menjadi referensi untuk pengembangan penelitian selanjutnya. Secara umum hasil penelitian seperti ini bisa terus dikembangkan dan mampu meminimalisir dampak negatif terhadap pernikahan dini pada remaja puteri.

3. Bagi tempat penelitian

Diharapkan guru bimbingan konseling memberikan bimbingan yang intensif, khususnya mengenai sex education yang bekerja sama dengan petugas kesehatan, sehingga dari bimbingan tersebut para siswa diharapkan lebih memahami mengenai berbagai pengetahuan tentang dampak pernikahan dini.

4. Bagi tenaga kesehatan

Diharapkan bagi tenaga kesehatan untuk lebih meningkatkan penyuluhan pendidikan kcsehatan kepada para remaja , khususnya remaja puteri mengenai pengertian, tujuan, penyebab serta dampak dari pernikahan usia dini untuk mengurangi kejadian pernikahan usia dini.

5. Bagi masyarakat

Diharapkan bagi masyarakat khususnya orang tua yang memiliki anak remaja puteri agar dapat memberikan informasi mengenai pernikahan dini serta dampak yang dapat terjadi akibat kejadian tersebut dengan cara mencari informasi sebanyak mungkin, sehingga diharapkan angka kejadian pernikahan dini dapat diminimalkan.

\section{DAFTAR PUSTAKA}

Afifah, N, K., dan Susilawati, D. 2016. Gambaran pengetahuan remaja puteri tentang dampak Pernikahan dini di desa lempong kecamatan jenawi Kabupaten karanganyar. Universitas Diponegoro.

Damayanti, I. 2012. Gambaran pengetahuan remaja puteri tentang dampak pernikahan dini pada kesehatan reproduksi siswi kelas XI di SMK Batik 2 Surakarta. Sekolah Tinggi IImu Kesehatan Kusuma Husada.

Kau, F,H. 2014. Faktor-Faktor Yang Mempengaruhi Pernikahan Usia Dini Di Kecamatan Limboto. Skripsi. Universitas Muhammadiyah Gorontalo. Gorontalo

Landung, J. Thaha, R. and Abdullah, A.Z.2009. Studi kasus kebiasaan pernikahan usia dini pada masyarakat kecamatan Sanggalangi kabupaten Tana Toraja. Jurnal MKMI. Vol 5 No 4. Hal 89-94

Pamangin, L,O,M. 2012. Faktor Yang Berhubungan Dengan Sikap Remaja Puteri Terhadap 
Pendewasaan Usia Pernikahan

Di Kelurahan Singki Kabupaten

Toraja Utara Tahun 2012.

Skripsi. Universitas Hasanudin.

Makasar.

Saswandy, I.R.A, 2014. Perubahan

nilai dalam pernikahan dini.

Universitas Maritim Raja Ali

Haji, Tanjungpinang.

Sugiyono, 2011. Metode penelitian

kuantitatif kualitatif dan R\&D.

Bandung: Alfabeta

Utami, T,I,W. 2013. Hubungan

Pengetahuan Dan Sikap Orang

Tua Tentang Kesehatan

Reproduksi Dengan Tindakan

Orang Tua Mengawinkan

Puterinya Diusia Remaja (Studi

Di Kecamatan Sukowono

Kabupaten Jember). Skripsi.

Universitas Jember. Surabaya. 